a progressive step, but for some of the older members it represented a step in the wrong direction. All agreed that it had a significant impact on the department and the college for many years.

Harry came to CSULA as an enthusiastic proponent of Philip Selznick's approach to political sociology, a course that Harry enjoyed teaching. Both Selznick and Harry were strongly interested in organizational behavior. Subsequently, IrvingJanis's Group Think (1972) had a strong impact on Harry's thinking and political analysis.

Janis's framework resonated with Harry and Jean's experiences at RAND. It also fit the behavior he observed among elite decision makers in the twentieth century in the area of nuclear policy in particular and more generally on the American political scene. Harry saw the impact of group think in the Vietnam War decision making as well as in Watergate and its aftermath. Consequently, Harry was attracted to dissident political leaders and presidential candidates such as Barry Commoner and Ralph Nader.

Harry and his wife, Jean, enjoyed good food and wine, which undoubtedly contributed to frequent requests for them to host department gatherings. They were gracious hosts, and both had a good sense of humor. Harry loved jokes, including self-deprecating shots such as convoluted instructions for assembling a reel-to-reel tape recorder that he read at his retirement in lieu of the recorder itself.

Because Harry did not like to drive the freeways, years before GPS he became an ace at finding expeditious surface routes to a host of locations far and near to his home. While traffic backed up for miles on the freeways, Harry scooted home on the roads less traveled. If you were lucky and had a chance to follow him from campus to his home, you learned alternative routes that you never imagined existed.

Loyalty was one of Harry's strongest virtues. He maintained relationships such as those with Alan Wolfe and his University of Chicago peers for years. At CSULA while other faculty sought the privacy of separate offices, Harry and I remained the only political science faculty who shared an office after the department moved from the third floor of King Hall in the 1970 s to the fifth floor of Engineering and Technology. We remained officemates until Harry's retirement in 1990.

Although Harry was justifiably proud of his long service with the university, his children, Carolyn and Brian, were his pride and joy. Harry's knowledge of dysfunctional organizational environments guaranteed that he and Jean were active participants in the Arcadia schools and in the gymnastics groups in which Carolyn starred. Harry and Jean were thrilled by Carolyn's successful dancing career and enjoyed traveling to see her perform. No parents could have been prouder and happier at the wedding of their daughter than Harry and Jean were at the wedding of Carolyn and Kelly. The joyous reception on the beautiful grounds of the Pasadena Historical Society is a fond memory for all those who attended.

Last December after losing Jean, the love of his life, in June 2007, Harry sent out a message that provided updates on both his children. Brian was working at Pasadena City College Library as a circulation supervisor while getting his master's degree in Library and Information Science. Carolyn just finished her first semester of a master's program in Marine Science at State University New York, Stony Brook, on Long Island. His message also indicated that Brian was living with him and that Carolyn was visiting regularly. It is clear that Harry was as proud of their loyalty as he was of their accomplishments.

Edward S. Malecki J. Theodore Anagnoson Emeriti Professors of Political Science, California State University, Los Angeles

\section{VIVIEN HART}

Vivien Hart, professor of American studies, died on February 2, 2009, aged 70.

Vivien described her own academic interests and work as the study of "contemporary constitutionalism." It was much more than that, however. In the first place she developed an interdisciplinary social science approach in a field dominated by legal expertise. Secondly, her work demonstrated a remarkable pattern as she traveled a path from examining the nature of dissent to seeking the sources in constitutionalism for the resolution and reconciliation of conflict, leading in her later work to contemplating the possibilities for broadening participation in the constitutional process.

Thirdly, she focused on the contribution of women to the constitutional process. Her book Bound by Our Constitution: Women, Workers and the Minimum Wage stands as enduring testimony to the value and need for painstaking scholarship. In addition to her own work, Vivien encouraged and promoted research by young women in particular as well as established international scholars. This led to the publication of two co-edited volumes, Writing a National Identity and Women Making Constitutions.

The following quotations from two eminent Canadian scholars underscore her immense standing:

Vivien was a true blue member of that elusive body, the community of scholars. She gave much to the corner of that community-constitutional studies-in which I reside, by helping us connect our own local studies to broader and deeper issues shared by other constitutional democracies. Her own work was a brilliant example of what is to be gained by applying the methods of social science and the sensitivities of the humanities to constitutional studies. (Peter Russell)

She was, as you know, a scholar of constitutionalism, and to that subject she brought a moral purpose, a depth of understanding, and an insistence on a generous, inclusive perspective that greatly enhanced our understanding of the deeper meaning of the concept. (Richard Simeon)

Vivien was a late entrant to an academic career. The turning point was at Harvard, when Professor Samuel H. Beer, the leading American authority on British government, became her Ph.D. supervisor. Their relationship grew into one of colleagues and friends, and over the next 35 years, there was a continuing flow across the Atlantic of information, analysis, and discussion.

Vivien joined the Sussex faculty in 1974 where she and Professor Marcus Cunliffe immediately formed an important collaboration. As a historian and a literary critic, Marcus teamed with Vivien, a social scientist, to forge ahead with American studies. When in 1991 the university established the Cunliffe Centre for the Study of Constitutionalism and National Identity, Vivien was the obvious choice for director.

This proved the perfect vehicle for Vivien to further her own research interests as well as to facilitate the work of younger scholars. She fostered links between the Centre and George Washington University, Ohio State University, and the University of Toronto. A series of international conferences followed resulting in numerous publications. 
Vivien's career expanded far beyond the University of Sussex. She was a visiting professor at Smith College and at Ohio State University, and held fellowships and scholarships from the American Council of Learned Societies, Massey College of Toronto University, the United States Institute of Peace, the Woodrow Wilson International Center for Scholars, and the Brookings Institution.

Vivien's pleasures and enthusiasms were many, and included her love of the outdoors, fondness for music and food, the reading of detective novels, and, most of all, her family and friends. These pleasures allowed her to play the academic game of "never too busy to talk to you" and "let's have another cup of coffee" when, in reality, she was one of the most dedicated and conscientious of colleagues and teachers. She was a thoughtful mentor to many students and colleagues both at home and abroad.

The following pleasures also leave us with cherished memories.

Outdoors: She organized and chaired a prestigious international conference at the Rockefeller Center in Bellagio, yet found time every day for a walk in the surrounding countryside?

Music: Her love of music is well known but how many were aware of her secret passion for American musicals, not Rodgers and Hammerstein, more Rodgers and Hart, and Cole Porter?

Food and wine: She could recite the menu at a Michelin three-star restaurant that she shared with her friends the Keefers over 20 years ago. More recently, she took great delight in the 10 euro lunches in southwest France. Vivien was a practicing helixophile-a collector of corkscrews to you and me.

Detective stories: Her taste paralleled her career. When I first met Vivien in 1974 she was reading Rex Stout, whose detective, Nero Wolfe, was a great foodie and orchid grower. She moved on to Robert B. Parker, whose private eye, Spenser, fought for justice in Cambridge, Massachusetts. There have been many others since, but none more so than Sarah Paretsky's tough female private eye, V.I. Warhawski.

Vivien did "grumpy": but then universities provide great opportunities for doing so.

Vivien will be fondly remembered by her family and many dear friends. A thoughtful mentor to many students and colleagues both at home and abroad. An enthusiastic world traveler as well as an energetic hiker.

\section{Joyce Gelb}

\section{SAM HUNTINGTON}

Sam Huntington's works were taken seriously by political leaders and informed publics around the world. He served in government and advised administrations, both Republican and Democratic. But if you asked Sam who he was, professionally, he would have said, I am sure, "I am a social scientist."

His total commitment to social science was visible in many ways. He was tremendously proud that Political Order and Changing Societies was for many years the most frequently cited work in political science. I remember him working for weeks to perfect the message of his speech as president of the APSA that social scientists have an obligation to truth and to the larger political communities they belong to, because their ideas can have great importance. While open to and interested in the work of historians, he strongly believed that historians and political scientists had different callings. He engaged one of the leading historians of the American Revolution in a (barely) polite but unrelenting public debate, because the historian challenged, not only the historical accuracy of the argument made by Louis Hartz in his book The Liberal Tradition, but also the legitimacy of making generalizations across time and space to explain the origins and consequences of that revolution.

The importance of making such generalizations and testing them was overwhelming for Sam. It was not enough to know the particular, however important that was. He told with pride a story about an argument he had had with a policymaker, about the incidence of future coups in a country that had just had its first coup. The policymaker said, "I know this country, I have lived here and worked here for years. People want things to settle down." Sam, recounting the incident, said, "but I knew empirically that across countries at this level of institutionalization, the first coup leads to an increased expectation that coups can succeed, so that after the first coup there will be a second coup and a third coup. And I was right." Up until the end of his working days, the highest praise he could think to bestow on a book or an article was, "this is a first class work of social science."

Because he was so committed to social science, he could be stern towards those less disciplined. One brilliant academic was being considered for a university position on the strength of his written work. Sam was opposed. "Will he train graduate students in social science?" he asked, throwing up his chin, and raising his eyebrows, implying that the academic in question would never do so in a million years, and so should not be hired. And woe to any academic, young or old, in whose work Sam found any intellectual sloppiness. Sam would not tolerate it, as he did not tolerate it in himself. I know of at least one 250-page manuscript that Sam wrote and never circulated because it was not up to his standards. He dropped another fascinating research project when, after a year or more or work, he judged that his arguments simply did not stand up to his own critical scrutiny.

I can think, therefore, of nothing I could say that would please Sam more than to call him the greatest American social scientist of his generation.

Stephen Rosen
Beton Michael Kaneb Professor
of National Security and
Military Affairs
Harvard University

\section{WILLIAM W. KAUFMANN}

William W. Kaufmann died on December 14, 2008, in his sleep, at the age of 9o. During the cold war, he was a key figure among the "defense intellectuals"-less famous but more influential than most-who moved freely from think tanks to the Pentagon to academia and back again, crafting the theories of nuclear deterrence and translating them to policy. Yet by the ' 8 os, in the final, rococo phase of the standoff, he'd come to reject much of his old thinking and emerged, quite publicly, as one of the defense establishment's most accredited critics.

He served as special assistant to the secretary of defense in every administration from John F. Kennedy's to Jimmy Carter'sall the while spending every Thursday and Friday at the Massachusetts Institute of Technology, where he taught the art and science of defense planning to 20 years' worth of graduate students, many of whom went on to prominent positions in the field themselves. (Only during the Cuban 